\title{
Becoming Self: A Legion of Life in a Culture of Alienation
}

\section{Introduction}

A classic example of the instability of selfhood is the Ship of Theseus. The cells of our bodies are constantly withering and being replaced, making us a living, breathing system of perpetual life and death. Rather than treating this state as a paradox or trying to constitute a dualist view of a temporal subjectivity separate from the body, one could look at the Ship of Theseus as a metaphor demonstrating that life and thus also the lived experience of the self is only possible if synthesis and change are involved.

An individual plank of a ship is not the ship, nor is the sum of the planks the ship. Moreover, in the case of an actual ship, it is probably only a ship through a human eye, an ecosystem for the bacteria and a home for the rats, for example. Yet, the ship sails. In other words "life presupposes living, and hence, is only thinkable as a process, while selfhood presupposes structure, something that maintains its stability" (Sauka, 2020a). Thus, the real paradox of being is constituted via the conditions that make a ship possible - i.e., the instability of selfhood (namely, the constant transformation of life as a process) is a necessary element for any kind of selfhood to emerge, while "selfhood" presupposes a level of consistency. The process of life is organized via an entity (a structure) that is only possible through change that is ultimately destructive for the identity of that entity and ultimately leads to its dissolution. The entity thereby strives to sustain its imagined stability, and to fixate itself, all the while relaying on the change that is the basis of its existence.

What would a stable, "transcended" human self, a uniform ego even entail? "I am I, times infinity" - a cartoonish image of a cancerous fixation in multiplicity, an identity frozen in time comes to mind. The living dead a stillness in death, but alive. Rather life - as it is perceived by the human ego, is expressed as a process (time) and a structure (materiality) - a synthesis of at least two elements, namely, a focused, organized movement.

Søren Kierkegaard famously expresses selfhood thusly:

"The self is a relation that relates itself to itself or is the relation's relating itself to itself in the relation; the self is not the relation but is 
the relation's relating itself to itself. A human being is a synthesis of the infinite and the finite, of the temporal and the eternal, of freedom and necessity, in short, a synthesis. A synthesis is a relation between two" (Kierkegaard, 1980, 13).

Synthesis and process always presuppose certain elements. The building blocks of life - a flesh, materiality that functions as an anchor, a locus for the ever-emerging, temporal, historical self.

This article aims to articulate selfhood in terms of a carnal body that functions as a locus for the conception of a historically construed yet material ontological disposition of the human being. It is presumed that such conceptualization enables a materially embedded genealogy of the present, which surpasses the boundaries of a dualist distinction of organic and inorganic "realm of life" and a "realm of things", rather situating the dichotomy of life and death within an ontologically embedded character orientation of a self or a culture.

This character orientation is expressed through the having and being modes of existence conceptualized by Erich Fromm - an ardent humanist thinker, whose descriptions of alienation and capitalism allow viewing the ontological considerations of carnal existence in a social and ethical context. Restated as becoming, the mode of being represents life as movement and perpetual change, whilst the mode of having is directly linked to the societal alienation as deprivatization and eugenization of the body.

Throughout this article I argue from a position sympathetic to the new materialist ontology, characterized by immanence - such that is employed by Gilles Deleuze and Rosi Braidotti, and influenced by Baruch Spinoza, Friedrich Nietzsche, and Henri Bergson ${ }^{1}$. This framework proposes immanence of existence, and the entanglement of social constructs, history, and materiality in meaningful materiality (as will be presented in the second section, via the analysis of a meaningful, senseful carnality) and allows to investigate the ontological situation of humanity genealogically, by ingraining meaning in the flesh (Sauka, 2020b; 2020c), and, with it, discontinuity and meaning in materiality itself, conceiving the world as an aesthetical phenomenon (Nietzsche, 1999a, 17).

\section{A carnal self}

Life is usually conceived in a dichotomy of death as its complete denial. From such opposition, which is evident only from ego- and anthropocentric view, follow other greater or smaller dichotomies, which lead to a dualist view of the organic/inorganic, nature/culture, and mind/body.

\footnotetext{
${ }^{1}$ See interpretations of Nietzsche and Bergson by Grosz, 2004 and Deleuze, 1991.
} 
Although these dichotomies have undergone a major upheaval in the last centuries, their prevalence in everyday thinking is undeniable (Rose \& Abi-Rached, 2013, 200-205). In social and human sciences, these have even become the core concepts, through which relations between humans and technology, industry, and ecology, etc. are examined. However, their self-evidence has been refuted not only in human but also in life sciences, where questions of a mind-gut link (Mayer, 2016), going as far as the influence bacteria has on decision making, and the like are gaining momentum today. In human sciences, these are paralleled with discussions in new materialism, as well as the phenomenology of Leib (the carnal body $)^{2}$, both of which could turn out to be a powerful tool for building a connection between human and life sciences in a post-ego-centric (and possibly posthuman) context.

In a situation where human relations with the inhabited biosphere are increasingly problematized through an invasive technologization (Böhme, 2008b), the core concepts of life and death, the organic and inorganic, etc. resurface and demand a new conceptualization (Braidotti, 2013, 105-142; Radomska, 2016) - one, which does not rely on these age-old dichotomies. However, the events of the Anthropocene, such as the blurring of the limits of the self and technology, the biological and the cultural, are rather evidence of the human ontological situation ${ }^{3}$, within a concrete cultural context, than an entirely new ontological phenomenon.

To understand this, the core concepts of phenomenology of the carnal body should be briefly introduced. These stem from two contrasting traditions - Nietzschean existentialism and the Husserlian phenomenology. Nietzsche situates the carnal body as the "big mind":

"Der Leib ist eine grosse Vernunft, eine Vielheit mit Einem Sinne, ein Krieg und ein Frieden, eine Heerde und ein Hirt. Werkzeug deines Leibes ist auch deine kleine Vernunft, mein Bruder, die du „Geist” nennest, ein kleines Werk- und Spiezeug deiner grossen Vernunft” (Nietzsche, 1999b, 39).

A Self in the context of the phenomenology of the carnal body is a carnal self, an embedded, grounded locus of the nature-culture continuum of its lifeworld. However, it emerges via the carnal body as a multiplicity. It is cultural, yet manifold, dispersed, unfocused, as a herd without a shepherd.

\footnotetext{
2 I choose to translate "Leib" as "carnal body" here. Thus, hereafter, where "carnal" or "carnality" is mentioned, please, refer to the German term Leib or leiblichkeit (see: Böhme, 2019, Waldenfels, 2000).

${ }^{3}$ Although ontology is in itself also historical. A similar approach is taken by Johanna Oksala, in her discussion of the necessity of a transcendental approach when discussing feminist metaphysics. See Oksala, 2016, Kindle Loc 125-130.
} 
For focused action, the "little mind" is, thus, needed. Nietzsche expresses it concisely: "Leib bin ich ganz und gar, und Nichts ausserdem; und Seele ist nur ein Wort für ein Etwas am Leibe" (Nietzsche, 1999b, 39). This quote supplements the previous one - the shepherd that is the "small mind" or the soul should not be viewed as the most important element of the herd. It is rather an element of the herd, an inherent part of what makes the herd what it is.

This quote by Nietzsche calls to mind another by Foucault:

“"'A soul” inhabits him and brings him to existence, which is itself a factor in the mastery that power exercises over the body. The soul is the effect and instrument of a political anatomy; the soul is the prison of the body" (Foucault, 1977, 30).

Although Foucault does not distinguish between Körper and Leib, as is (variously) done by both traditional and new phenomenologies, in his texts body appears not only as a locus of social discourse - namely, as "the docile body" that is normalized and disciplined, but also as materiality. The normalization, however, does not happen via a pre-discursive nature or biology - it is the soul, i.e., the cultural, societal constructs that codify the flesh by inscribing history in the body, making it a historical body.

Conversely, materiality might be the site for experimentation and freedom, which enlivens "resistances" to the powers that normalize and objectify. This is also highlighted by Johanna Oksala:

"What Foucault suggests [..] is that it is in the body that the seeds for subverting the normalizing aims of power are sown. The body is a locus of resistance and freedom. [..] The body is never completely docile and its experiences can never be wholly reduced to normative, discursive determinants" (Oksala, 2014, 93).

In this way, the body (and with it - also biology) emerges by Foucault as a locus of creativity, if viewed outside a dichotomy of pre-discursive and discursive understanding of the body (Sauka, 2020b, 8-10). This interpretation is strengthened by Sarasin (2009). The author argues that Foucault's cultural code is inscribed in the flesh, gaining facticity, yet biology is also cultural, promoting an element of irrationality and aesthetical freedom. This, of course, is only understandable from a point of

\footnotetext{
4 "The body is never completely docile, and its experiences can never be wholly reduced to normative, discursive determinants. The sexual body is always discursive in the sense that it is an object of scientific discourses and disciplinary technologies. Nevertheless, it is also a body acting in the world and experiencing pleasure. And a distinction must be drawn between discourse and experience, even if we accept that language forms the necessary limits of our experience and thought” (Oksala, 2014, 93).
} 
view, where nature and culture are understood as a continuum and meaningful, senseful materiality at that. The biological is, thus, not to be understood in a mechanistic context (Braidotti, 2013). What Foucault highlights is that biology and culture must never be separated in a theoretical contemplation.

A view of the docile body vs creative materiality largely matches the concepts of the phenomenology of the carnal body, where "carnal body" is situated as the "nature that we are" (Böhme, 2008a, 2019) through a reinterpretation of Helmuth Plessner's formulas of eccentricity "Leibsein" (Böhme, 2003, 26; Fuchs, 2013, 82-93; et al.) - a locus of a nature-culture continuum, which, via an alienated I-consciousness (or ego-function ${ }^{5}$ ) constructs the "body that we have" conceived in the formula "Körper Haben” (Böhme, 2003, 26; Fuchs, 2013, 82-93; et al.). Here, again, the "small mind", conceived as the I-consciousness, is an inherent part of the carnality, subordinated to the carnal body, yet also the origin of its self-alienation, which results in a body image projected by the I-consciousness, for the perception and conceptualization of the carnal body and via this figure - also the surrounding world (Waldenfels, 2000).

One is split into three - the carnal self is experienced via an I-consciousness (as its correlate) that projects the figure of an "anatomical body" (this figure can also be of any other types of bodies - such as the "sexualized body", for example). The figure that is created corresponds to the normalized, "docile", discourse-ridden socially transmitted body, subjected to historical transformations.

Thus, the answer to the question, why do the dichotomies of mind and body continue to haunt us in the $21^{\text {st }}$ century, seems easy to grasp it is a combination of the way the mind works (i.e., the self-alienation of the carnal body through the genesis of an I-consciousness) and the ego-centric social context of the Western society. From the standpoint of an ego, a certain level of alienation from the carnal body, imagined (and construed) as a tool or an objective thing, is always present, and is amplified by the way contemporary Western society is organized.

The carnal self is always already alienated, "split" between the immediate carnality and the socially construed body - an inbetweenness that is, nevertheless, not to be misinterpreted as an inbetweenness between nature and culture. The phenomenology of the carnal body thus describes the inbetweenness experienced by humans - a reflected state of synthesis and controversy, which allows the I-consciousness to view the world in

\footnotetext{
${ }^{5}$ I use "ego-function" and "I-consciousness" interchangeably. In short, I refer to the I-consciousness in a strictly phenomenological context (Ich-Sein) and mention ego-function to highlight the conceptual link to psychoanalytic discussions.
} 
dichotomies of body and mind, immanence, and transcendence, etc., and to long for a solution for this state, either by "returning/descending to nature" or "overcoming" and "transcending" the carnality. This ontological disposition also describes the historicity of the body image; however, it does not presume the historicity of the carnal existence itself.

Namely, phenomenological structures largely suppose the self to be a) either defined by the alienated I-consciousness, which constitutes the historical body image, thereby enabling the cultural dimension of life (carnality here is entirely biological and accessible only via the body image) or b) constitute a carnal self, which is both cultural and biological, yet also historical only through the medium of the I-consciousness, thus foregoing the embeddedness of the carnal body within its environmental milieu (or - the transcorporeality of the carnal body (Alaimo, 2010) that originates culture before the I-consciousness.

However, in the context of nature and culture understood as a continuum (Braidotti, 2013), Nietzsche's concept of the history in flesh and Foucault's view of discourse in bodies (as expressed by Philipp Sarasin, 2009, and Johanna Oksala ${ }^{6}$ ) can be employed to supplement the phenomenology of the carnal body with the notion of a historical, genealogically conceived carnality. A conceptualization of culture before the I-consciousness, not only in terms of biology as an enabler of the cultural sphere but also in terms of an integrated nature-culture continuum (justified, for example, by the existence of non-human cultures, discontinuity of nature in sexual selection ${ }^{7}$ and the participation of all carnal processes in the realization of cultural activity ${ }^{8}$ ) allows integrating Foucault's view of historical materiality and the phenomenology of the carnal body in terms of a historical carnality.

This view is justified also by the latest scientific discoveries in disciplines such as epigenetics, which contribute to the understanding of carnality as a historical and transformative site of nature/culture synthesis. Culture, thus, does not only affect the experience of the body in society - it does, in fact, also affect the facticity of Leib. War, famine, but also cultural idiosyncrasies, such as diving for food (Morgan, 2018), can affect the genetic and physical make-up of the body. When combined with the undeniable carnality of all human activity, it becomes clear that emotional and symbolic phenomena can also be inscribed into

\footnotetext{
6 "What Foucault suggests in this paragraph is that it is in the body that the seeds for subverting the normalizing aims of power are sown. The body is a locus of resistance and freedom (see also Foucault, 1980a, 56)” (Oksala, 2014, 93).

${ }^{7}$ On sexual selection as an aesthetical, symbolical sign process, see Sarasin, 2009; Grosz, 2004.

${ }^{8}$ Demonstrated by unconscious decision making, mind-gut connection, etc.
} 
the carnal memory via epigenetics. This is, however, not a reductionist view - rather a refusal of the dualism altogether, which allows viewing Foucauldian discourses as more than mere language constructs and the biological make-up of the body in the terms of a senseful, meaningful carnality.

Conversely, the historical materiality, i.e., the carnality of the human being, leads to a reconsideration of the dichotomy of life and death. In what contexts does this dichotomy exist, if the I-consciousness, usually positioned as its locus, exists only as a correlate to the historical materiality of the carnal existence?

\section{A legion of life}

The carnal body is usually described as pathical and responsive the immediate affectivity. Yet, it is not passive - carnality resides in all human praxes and the self-alienation of the carnal body does not entirely exclude carnal experience - although social life is often organized via the body image projected by the I-consciousness, which allows this body image to be socially constructed and historical, carnal embeddedness is also revealed experientially and grasped by the I-consciousness to a smaller or lesser degree. This is due to the primacy of the carnal body, its activity, and presence in any symbolic or bodily practice as an independent self, focused by the I-consciousness. Sickness and pleasure, grief, "butterflies in the stomach", but also such undeniably cultural activities as playing a musical instrument or writing an article are all undeniably carnal activities - the body is not simply a tool or a passive backdrop for symbolic action. When playing a sonata, the I-consciousness is often only an observer, whilst the carnal practice takes place.

The "small mind" or the I-consciousness functions rather as an attribute for focus and structure. In human consciousness, this cognitive power also has a reflective function - to reflect that one is reflecting. With this the discussion of life and death as the immediate dichotomy via the I-consciousness resurfaces.

I-consciousness is, consequently, a vehicle for the transportation of the will. The carnal body, however, is not without agency - it is a locus of nature and culture combined, and as such it has immediate access to the world. Thus, the recognition of a self as a self in I-consciousness is an ultimately secondary function. It is obvious that something can be recognized (i.e., reflected) only as an afterthought (though, almost immediate) to its existence. This is recognizable in small babies, and in some cases - sickness or old age. Not all people have a fully functioning I-consciousness, which does not exclude these from the human lifeworld 
or experience. One is born human ${ }^{9}$ (a full-fledged, carnal, material self) and does not become one, for example, as one becomes a doctor in philosophy on a linear (or winding) path from point A (being accepted by a university) to point $B$ (defending the thesis), even though the state of being human is a perpetual becoming. ${ }^{10}$ The recognition of a self as completeness in its multiplicity is, accordingly, also deeply embedded in an intercarnality - the otherness that anticipates and enables the formation of an I-consciousness on an ontogenetic level, as is often assumed by traditional phenomenological accounts. Namely, the self is not the inbetweenness of an I-consciousness between nature and culture or a biological and cultural sphere, rather the carnal body itself is a synthesis that presupposes inbetweenness (eccentricity) and overcoming as its significant characteristics transferred via its correlate - the I-consciousness.

If the I-consciousness or the "small mind" is neither the primary medium of culture nor the only origin of culture, the senseful agency must find its anchor site in the carnal body as a representative of life. It is perhaps noteworthy to say that here I refer to life, understood as senseful materiality. The posthumanist thinker Rosi Braidotti expresses it concisely:

"Living matter - including the flesh - is intelligent and selforganizing, but it is so precisely because it is not disconnected from the rest of organic life. I therefore do not work completely within the social constructivist method but rather emphasize the non-human, vital force of Life, which is what I have coded as zoe" (Braidotti, 2013, 60).

Thus, the multiplicity of the carnal body unveils itself as a vehicle of life, a locus, for the individual self, as a process, to take place. As a separate entity, it is an individual cluster of the material and historical powers of life. The carnal body is already a self (even before an I-consciousness can functionally arise), insofar as it is recognizable by another as a structure. Intercarnality ${ }^{11}$ and the primacy of the Other comes into focus (Levinas, 1969; Waldenfels, 2004, 235-248; Waldenfels, 2007; et al.). Life - as it

\footnotetext{
${ }^{9}$ Being born is, again, carnal evidence for the primacy of otherness and the primacy of the carnal body. It is also evidence of life being the synthesis of materiality and change via becoming. See: Oksala, 2004.

${ }^{10}$ A different article should perhaps examine the impossibility of becoming and overcoming if such a "becoming human" would be assumed, as it seems that the two different conceptions of becoming would be incompatible - if one becomes human and then is human, then there is no other path left for development - one already is this fixed something that is called "a human".

${ }^{11}$ Instead of intersubjectivity, the material carnality allows to position Zwischenleiblichkeit, i.e., an intercarnality, which rests upon the primacy of the carnal body- this way a bond between subjects is shown as primordial, material, self-evident, before the rational action of building such a bond is even possible (in pregnancy, etc.).
} 
is understood through the eyes of the ego, is expressed as a process and a structure - a synthesis of at least two elements, i.e., a focused movement.

The multiplicity of the carnal body thereby mirrors the manifoldness that is life. An ego is enabled by the creative powers of the carnal body. However, the construction of such an ego presumes that a body image a figure of an anatomical body - is constructed.

The self, as an embedded, carnal entity experiences aging (and imagines dying) via the ego function (or functions), as a dissolution of the carnal body through the dissolution of the figure of the anatomical or culturally constructed body. Simultaneously, this dissolution is also sensed immediately as a carnal experience of lost stability. The striving for stability in the ego is always at odds with the multiplicity of one's carnal body - life is experienced only as multiplicity, a movement, and, thus, the ego, which is formed to focus the dispersed multiplicity, creates an inner paradox, a tension, which characterizes human life. This tension is paralleled by the drive of survival, expressed in the Darwinian idea of a struggle for existence. As culture is not a uniquely human sphere, the ability to reflect is present in the forms of life to various degrees, even though the ability to reflect upon reflection, i.e., the I-consciousness, might be a uniquely human characteristic to a certain extent.

The materiality of the carnal body is mediated by the ego via the construction of a figure of an anatomical body - a body experienced not only as the self but also as a tool and a property. Hence, humans are able to construct the figure of an anatomical body, a body, experienced not only as the self but also as a tool and a property, predisposing humankind to be more likely to try to fixate and overcome their temporal and spatial limits, i.e., their finitude and mortality. Hence, the human ego is the ultimate tool for self-preservation by overcoming one's nature. Where animals (for whom an inner balance between the powers of structure and movement is more often achieved) try to adapt, humans transform - the drive for the stability of the ego enables civilizatory processes - the taming and transformation of what is reflected upon as "nature" (via the self-alienation processes).

Here, the concept of life emerges in a paradoxical light - as a synthesis, it is only possible as a tension between movement (transformation) and structure (fixation). The structure of the carnal body reflects and intensifies this tension by the construction of an objectified figure of the body as a fixed, stable grounds for the construction of an embodied stable ego-centered subjectivity. In the plane of immanence, the structures of life as individual or intercarnal entities are experienced as "the body without organs" (Deleuze, Guattari, 2000, 281) - as a body that in each separate state strives to erase processes of differentiation, which 
make its existence possible. The concepts of life and death are, consequently, relative to the formation and dissolution of ego-structures (as well as structures of consciousness in other animals).

\section{The death drive}

A stable self is impossible - it would be a cancerous fixation, a self-replication, a lethal immobilization of all processes. Such stability would be deadly without variability and change. Hence, by abandoning ego-centricity inherent in the dichotomy of life and death, the major drives of life and death, coined by Sigmund Freud, might acquire a new dimension. Namely, "beyond the ego principle" an answer to the question of the origins of a death drive becomes clearer.

From the aforementioned, one is perhaps inclined to deduce that my aim here is to switch places of both major drives. It is, indeed, possible to conceptualize life and death oppositely to how they are usually perceived. Isn't the death of selfhood, in its essence, the dispersion of life forces, through the forces of variability and differentiation, and, consequently, in a sense, also the ultimate victory of life over fixation and ego-organization, which means that Eros or the drive of life (paralleled by the processes of sexual selection) somehow stems from the drive for the annihilation of the self - or, in the words of Nietzsche - the Dionysian principle? And isn't death drive, in contrast, the drive of self-preservation, of fixation and stabilization of a concrete self, and, thus, the ego's drive for survival?

Yet, all is not that simple. Both drives - functioning separately could be understood as both productive, as well as lethal and destructive - yet each is essentially a drive necessary for the tension and ultimate dissolution of life. Where the life of an entity or a self is understood only as a quasi-paradoxical union of tension and synthesis, the "drive for life" as Eros and the "death drive" both represent an inner synthesis of the powers of life. Both point towards overcoming - either in multiplying or fixation, and promote dissolution, as either a fusion with others and otherness (in Eros), or a loss of the self (in the death drive) - both forms of multiplicity in oneness, as well as possible vehicles of self-annihilation.

Either extreme - a fixation or a complete dispersion - can destabilize life forces and enforce the dissolution of an entity, yet beyond "the ego principle" there is no ontological duality of life and death, only the transformative flow of forces of organization and transformation. From an ego-centered viewpoint, the drive for life and the death drive is a distinction embedded in the different expressions of the instability of selfhood, 
nonetheless, the potentialities of dissolution and fixation are inherent in descriptions of both.

Individually, the two drives for stability and dispersion would both achieve death (understood as the dissolution of an entity or selfhood), as well as their combination is maintaining the continuation of life, and, even though individual life of a self is perceived as possible as a tension between the two, they are both rather mere representation of the forces of fixation and transformation - i.e., the forces that they mean to represent are equally inherent in both.

I came upon the problematization of the death drive in the works of Erich Fromm, who insists on viewing the "death instinct" as a psychopathology (Fromm, 1964, 20). Upon stating this, he maintains that:

"The contradiction between Eros and destruction, between the affinity to life and the affinity to death is, indeed, the most fundamental contradiction that exists in humankind. This duality, however, is not one of two biologically inherent instincts, relatively constant and always battling with each other until the final victory of the death instinct, but it is one between the primary and most fundamental tendency of life - to persevere in life - and its contradiction, which comes into being when man fails in this goal. In this view the "death instinct" is a malignant phenomenon which grows and takes over to the extent to which Eros does not unfold. The death instinct represents psychopathology and not, as in Freud's view, a part of normal biology. The life instinct thus constitutes the primary potentiality in man" (Fromm, 1964, 19-20).

His statements here and in other works, concerning Freud, at first struck me as peculiar, yet they made sense in an ontology imagined "beyond the ego principle". Namely, if one abandons the ego-centricity of ontology, it becomes clear that there is no death outside of selfhood, but only life - a variable existence in different states of being. Consequently, the dichotomy of life and death does not exist outside of a structure or ego-centered view, where individual entity emerges as a senseful synthesis and tension of the two elements of materiality and movement, fixation, and differentiation.

Death, then, is only a name for the dissolution of the tension of the forces of structure and temporality, thus, the inbetweenness of the carnal self is experienced as a perpetual search for the self in either immanence or transcendence ${ }^{12}$, which, again, both are characterized by dispersion and fixation. This non-identity with the self is the only possible self, experienced as the becoming self, the unsolvable tension of the forces of life.

${ }^{12}$ See Kierkegaard, 1980 for a discussion of running away from the self and toward the self. 
Accordingly, both of Freud's major drives (possibly paralleled by the struggle for survival and the sexual selection) are, hence, essentially tied to an organizing and transformative powers of life and represent different ego expressions of the same self-organizing powers of life.

A drive for fixation of the ego, found in the drive to multiply in Eros, as well as in the drive to encapsulate oneself through the cessation of all movement and transformation in the death drive is revealed as the necessary expression and experience of the tension between fixation and transformation in the becoming self. Similarly, the drive for dispersion found in Eros, as well as the drive to destructiveness are also expressions of this same tension.

Thus far, Fromm seems to be right, in the sense that the experienced duality is not ontologically grounded. However, where does a psychopathological "death drive" appear?

The play of powers roughly translates to Nietzsche's concepts of Dionysian and Apollonian - the flow and the structure (Nietzsche, 1999a). The third element - the Socratic principle, however, brings us to the way that Western civilization has appropriated these elements of tension between the powers of structure and change into the current culture, often characterized by alienation, facilitated via the self-alienation of the carnal body.

In this way, nature turns against itself by the alienation of the ego from its embeddedness of the variability that is its carnal body. The self-alienation achieved through the ego allows the self to perceive its carnal multiplicity and instability as an enemy for its continued existence. Hence, the human ego tries to control and transform the power of life, experienced as the grounds for the instability and inevitable finitude of the ego's existence.

With the concepts of having and being Fromm establishes a distinction between a social and characterological directionality toward activity and creativity (being) or destruction and control (having) (Fromm, 1976). Fromm also differentiates between two possible conceptions of having as a mode of life, here conceived as the drive for structure, stability, and fixation. That is, he differentiates between existential having (Fromm, 1976, 85-86) as a necessary mode of perceiving the world as an object ${ }^{13}$ and having as a characterological drive of destructiveness and consumption, which, in Fromm's view, significantly characterizes the society of

13 “...human existence requires that we have, keep, take care of, and use certain things to survive. This holds true for our bodies, for food, shelter, clothing, and for the tools necessary to produce our needs. This form of having may be called existential having because it is rooted in human existence. It is a rationally directed impulse in the pursuit of staying alive” (Fromm, 1976, 85). 
his time as alienated, mechanized and lonely. This distinction allows positing being and having as complementary to the threefold structure of the carnal body, where the existential having, posited by Fromm, matches the unavoidable self-alienation of the carnal body. Thus, Fromm's concepts of being and having allow linking the ontological disposition of inbetweenness between Leib Sein and Körper haben with the social situation of human beings, where the construed body image plays the role of a necessary (in case of existential having), yet often amplified civilizatory function.

One is often compelled to think that the mode of having (as a function of subject-object differentiation) is the only possible medium, a precondition of culture. Similarly, inbetweenness often is expressed as a state, between animality and "full humanity"14, possibly achieved by the overcoming of one's mortality and animal characteristics.

In the works of Fromm, being, however, is also expressed as an inherently cultural mode of existence, and a choice to live and act either in the mode of being or in the mode of having (either on a societal or individual level) is accentuated (Fromm, 1992a). I argue that this becomes clear in life understood as senseful materiality, where the human-specific self-alienation of the ego is not the only possible medium of culture, although a major vehicle for the civilizatory process.

Coined this way, the alienation of the contemporary culture in the mode of having can be understood as both an existential necessity (stemming from the self-alienation of the ego), and an expression of human ego-centricity in particular social settings, with the potential of pathological forms. The inbetweenness is then rather the experience of the tension of life in reflection than a contradiction of nature and culture in humans.

A clear link is, thus, possible between the conceptual pair of being and having and the understanding of death drive, as the basis of human destructiveness. In a sense - Fromm is perhaps wrong in thinking that the primary drive of the human being is the drive for life, insofar as his argumentation does not go "beyond the ego principle" - the mediation of a carnal entity via ego functions is characteristic to many forms of life. However, the self-alienation of the human ego, able to not only objectify its body through the construction of a body image, but also to reflect upon this construction, is human-specific, and thereby arouses several consequences, one of which is a transformation of the force commonly perceived as the "death drive". Human destructiveness is, consequently, borne out of a specific form of self-alienation, enabling alienation in culture, conceptualized in Fromm as the mode of "having" and goes beyond

${ }^{14}$ This is a viewpoint upheld by Fromm himself (see: Fromm, 1992b, 222-223). 
"existential having" or the forces of self-preservation and fixation, ingrained in the self through the synthesis of materiality and process.

A distinction of a death drive and Eros is, thus, impossible on an ontological level, as they both represent the powers of preservation and fixation, yet the descriptions of both Sigmund Freud and Erich Fromm represent two different perspectives of the experienced reality. The first represents the phenomenological reality, inherent in humans via self-reflection of the ego - an unavoidable perception of the dichotomy of life and death through the inbetweenness of the human being (as an ego function of self-reflection and the experience of selfhood, rather than an ontological disposition between nature and culture). The latter, even though it is not the author's intention, represents the ontological dimension, beyond an ego-centric view, pointing toward a necessity for a (probably critical) posthumanist dimension in ethics, for the solution of contemporary ecological and societal problems. ${ }^{15}$

In this context, in an analysis of the characterological expression of the elements of creativity (as being) and self-preservation (as having), the concept of being should rather be restated as becoming, to express the ontological disposition underlying the characterological decisions available to men. Fromm oftentimes highlights human being as a being in progress ${ }^{16}$, as a being that probably is "not born yet"17, and even though he describes himself as a radical humanist ${ }^{18}$ (and in some aspects nears transhumanist thinking) $)^{19}$, processualism and unfinishedness

\footnotetext{
${ }^{15}$ Fromm himself is, however, perhaps more optimistic than me and attributes his theory also to the perceived reality, constituting in humans only the drive for life also from the standpoint of what would be constituted as an ego-centric ontology in this paper.

16 "The subject matter of the "science of man" is man: man as a total biologically and historically evolving being who can be understood only if we see the interconnectedness between all his aspects, if we look at him as a process occurring within a complex system with many subsystems" (Fromm, 1992b, 115).

17 "Indeed, if we look at man's development in terms of historical time, we might say that man proper was born only a few minutes ago. Or we might even think that he is still in the process of birth, that the umbilical cord has not yet been severed, and that complications have arisen that make it appear doubtful whether man will ever be born or whether he is to be stillborn" (Ibid., 251).

18 "By radical humanism I refer to a global philosophy which emphasizes the oneness of the human race, the capacity of man to develop his own powers and to arrive at inner harmony and at the establishment of a peaceful world. Radical humanism considers the goal of man to be that of complete independence, and this implies penetrating through fictions and illusions to a full awareness of reality" (Fromm, 1966, 13).

${ }^{19}$ In many respects, Fromm believes in the human capacity to overcome nature by the power of reason, yet his existential and ethical stance often allows a posthumanist reinterpretation. See: Fromm, 1964.
} 
demonstrate Fromm's concepts in a posthumanist light ${ }^{20}$. As a processual, active, creative participation, being translates into becoming and expresses the full potentiality of a living entity. Through the prism of Fromm, becoming and having, it grows even clearer that experience reveals both having and becoming as transmitters of culture and indicates an amplified ego-function to be the transmitter of an imbalance between becoming and having in contemporary culture, directed towards rationality, control, and objectivization as the expressions of the structure and fixation facilitated by a directionality towards having. The "death drive" here emerges in a pathological form, as a drive to rationalize and destruct, as a means of restructuring and controlling life forces. Thus, the concepts of becoming and having allow expressing the alienation of contemporary society, as well as an ontology characterized by process, historicity, and discontinuity, upon the basis of nature and culture as a continuum.

\section{Alienation in culture}

despite the increasing evidence against it, the dualist paradigm continues to dominate everyday practices, especially in the form of scientific reductionism - a "reversed dualism" (Sauka, 2020c). As demonstrated in the previous section, the alienation of the anatomical, construed body is realized via the alienation of the I-consciousness of the lived, carnal body. To a certain extent, the conception of the world as an object is, hence, necessary for the anchoring of an I-consciousness, i.e., for the perception of a stable self. If we are to function, we must distinguish ourselves from the world as a separate structure. However, as we are also always immediately carnal, the degree of the alienation can vary. In a culture, which chooses to ignore the immediate carnal presence of the self, alienation can lead to undesirable results, which are especially noticeable in the perception of otherness, including the perception of the non-human other ${ }^{21}$.

${ }^{20}$ This view is strengthened by passages such as this: "We had concluded that the full humanization of man requires the breakthrough from the possession-centered to the activity-centered orientation, from selfishness and egotism to solidarity and altruism" (Fromm, 1992a, 1).

${ }^{21}$ The problem of "subject-object" oriented culture is highlighted in Martin Buber's work "Ich und Du", as well as the works of Emmanuel Levinas and many others, by problematizing the loss of a "third" element in the contemporary Western culture. A further study of otherness would reveal that the identification of a "third" element necessitates the understanding of the body as responsive and pathical, to overcome an objectivization of the "other" (in self and the surrounding world). The perception of otherness mirrors the perception of the self and impacts the discourse practices of social relations. This would be a topic for further study (Buber, 1923; Levinas, 1969). 
The abovementioned dualism is expressed in the everyday practice in three social paradigms and their combinations:

1) In the form of a traditional (often religious) dualism;

2) In the form of naturalism or a "call back to nature";

3) In the form of a reversed dualism in scientific reductionism.

Each of these paradigms is based on the same ontological presupposition of a qualitative distinction of mind and body (as well as nature and culture). Each also seems to bear dangerous consequences for humanity, moreover, the world. It might seem strange that an elevation of spiritual values is dangerous or undesirable, yet, as the world has seen time and time again, an increased value of spirit often necessitates a devaluation of the carnal self in the form of eugenization or deprivatization of the body. The biopolitics of population control (forced sterilization, gender-biased abortions, etc.) is a clear example of the elevation of rationality over carnal experience with disregard of carnal, emotional consequences of seemingly rational decisions ${ }^{22}$. Such devaluation of the body and nature can only be possible, in a situation where flesh can be commodified and objectified, "stripped of spirit", as a mere object to be manipulated with. Similarly, the workforce in capitalism has also undergone extreme mechanization and deprivatization of the worker's biopower - a worker is a machine that needs maintenance through sleep and entertainment, yet their everyday work practices are often alienating and mechanistic, resulting, for example, in depression (Hari, 2018). The examples are plentiful and discussed in many sources, in the works of Fromm, Foucault, Agamben et al.

In the light of such occurrences, an opposite road of discourse, promoting a "return to nature", is often embarked upon. Today we can see that increasing technologization, mechanization of labor, the medicalization of life (especially in reproductive medicine, palliative care, and psychiatry) (Foucault, 1965; Illich, 2016), genitalization of sexuality (Laqueur, 2004; Laqueur, 1992; et al.), and other similar phenomena are often met with suspicion, encounter counter-movements, and resistance powerful trends for the return to nature, going as far as the anti-vaxxer movement. In addition to seeming dangerous, both extremes appear to be stemming from inadequate ontological presuppositions.

The first assumes a dualist outlook that has gradually grown into a reversed dualism - a scientific reductionism that (in general) accepts the body as the "given objectivity" and mind or I-consciousness as the "unstable subjectivity". Stemming from the $19^{\text {th }}$ century's hygenization and biologization of the body (Sarasin, 2000, 11-31), instead of the previous, religiously based dualism, the reversed version of dualism

\footnotetext{
${ }^{22}$ See, for example, the movie by Christ and Dörholt, 2018 - "A lack of women in Asia”.
} 
places body above mind (or "soul") in its value hierarchy, yet does not refute dualism in general. This way it secures the alienation of the body, whilst the objectivization of the body loses all grounds of subjectivity.

The second tries to reconcile the body and the mind by a refutation of the dualist thinking, although seeming to ignore the circumstance that the human being cannot "return to nature", as being human has always entailed certain eccentricity of inbetweenness. Instead of an objectified, scientific body, the "naturalists" propose a kind of "revitalization of a vitalism", yet this is also a dualism in disguise - in their denial of "the cultural" it is situated as an essentially foreign, unnatural sphere of existence. An abomination, destined for destruction, an enemy in ourselves. This is understandable, as the alienation of culture might lead to a pessimist view of such an alienated existence, while it is also highly utopian, as well as dangerous in some cases (such as the "Church of Euthanasia" or the anti-vaxxer movement). This can be concisely expressed in the terms of a "nature $v s$ technology" duality and is akin to the passive nihilism ${ }^{23}$ paradigm coined by Deleuze as a term expressing Nietzsche's views on Buddhism as the ultimate consequence of Western nihilism.

The phenomenology of the carnal body, as considered before, tries to overcome these conflicts, by a refutation of the dualism, nevertheless, the conceptual grounds of "carnality as the nature that we are" and "body that we have" can also be misleading, if one contrasts "nature" with "technology", and denounces the latter, because it is only mediated through the alienated objectivity of the "body that we have". An immediate carnality is a given in every aspect of human existence, from the very basic functions of eating, sleeping and moving, to all manner of emotion, symbolic and cultural practices - in this sense, the phenomenological theory accepts the necessary carnality of all action.

The human condition of eccentricity, however, does offer several ways to conceive this carnality, which is often employed as a tool for the critique of technology by contrasting nature with technology (Böhme, 2019, 30-38). Such opposition is only possible, if one considers the carnal self to be chiefly (or only) mediated through the alienation in "the body that we have", which, in turn, is only possible, if one accepts the immediate carnality as a thoroughly passive phenomenon, without any means to mediate its inherent cultural potential to the world.

The relations with technology and other "inorganic prosthesis" can, thus, be encumbered by an unnecessary dualist outlook. A synthesis is,

23 “Told in this way, the story still leads to the same conclusion: negative nihilism is replaced by reactive nihilism, reactive nihilism ends in passive nihilism. From God to God's murderer, from God's murderer to the last man” (Deleuze, 1983, 151). 
however, possible. Rather than denying the role of "inorganic prosthesis" in our lives, the problems stemming from the alienation of today's culture must be sought for in the directionalities of becoming and having that the cultural discourses hold, rather than problematizing the technologies (and, consequently, also the civilization) themselves. In this way, the critique of technology can be expressed through and with the critique of capitalism, as an accumulation of the having direction, as it is done in the works of Erich Fromm, placing the responsibility for the ego-centricity and alienation of contemporary society upon a social, rather than on an ontological expression of the mode of having.

\section{Conclusion: On becoming self}

Philosophical anthropology (Friedrich Nietzsche, Max Scheler, Helmuth Plessner, etc.) has traditionally conceived the human disposition in the terms of an inbetweenness, which often situates human beings between nature and culture, attributing indeterminateness, irrationality, and a certain longing for overcoming as significant characteristics of the human condition. However, the phenomenology of the carnal body, in line with contemporary life sciences, reveals that the I-consciousness is rather an observer of the state of inbetweenness than its origin, as it is not the origin of all cultural activity. Culture is rather an inherent part of nature, as the carnal self mediates cultural practice immediately, without a medium of the I-consciousness. The experienced inbetweenness is, thus, the experience of being between the two directionalities of life as a tension of historicity and materiality - the becoming (related to the immediate carnality) and the having (objectified body image).

Both represent the tension that is life as the synthesis of temporality and spatiality, the dissolution of which is death as fixation of the spatial structure (stopping of heart, brain function, etc.) and the diversification and amplification of the temporal/transformative factor - the dissolution of the ego, the transformation of energy forces. The having directionality of life is, therefore, neither a uniquely human characteristic nor the only medium of culture - it is a necessary part of being, although human inbetweenness, which functions as "being self and experiencing it, too" amplifies the alienation expressed in the having orientation, predisposing humanity to excessive rationalization, control, etc., which are the trends underlying current discourses of deprivatization, eugenization, objectivization, etc.

Clothes, pens, glasses, eating utensils - these are all functional tools that have existed for centuries and become part of our lifeworld. The ease, with which we as bodily beings seem to incorporate "inorganic 
prosthesis" in our everyday practices, seem to articulate an authentic, immediate carnality (leiblichkeit) - the presence of flesh that allows building a synthetic relationship with the environment, without the medium of an I-consciousness, which often partakes in symbolic and undeniable cultural practices, such as sewing, playing music, dancing mainly as a spectator, as an observer that is rationalizing an action, emotion or decision made by the carnal self.

Hence, technologization does not overtly change the ontological situation and neither is it "unnatural" or completely foreign to true human nature. The same can be said not only of the relations between carnal bodies and inorganic prosthesis but also of human relations, i.e., of the relations between several selves. The ontological make-up presupposes a striving for an ego-centric self, for the preservation of a living system - a process that is dependent on the tension of historicity and materiality. This is expressed by the dichotomy of becoming and having. A common misunderstanding is a supposition that having directionality of life is the only possible medium of truly human - cultural existence. This is, however, not the case, if a historical, senseful materiality of the carnal body is assumed. Culture is already inherent and primordial to the I-consciousness, which experiences both directionalities, but mainly actively functions through the having directionality in the contemporary Western culture.

Conversely, having orientation is always already present in human relations with the surrounding world and is a necessary tool for experiencing selfhood (as fixation) in a world of otherness. This is especially evident in a discussion of life and death - the dichotomy that functions only in an ego-centric setting and has no ontological foundation in the way it is perceived in everyday life. The ontological instability of the self (which is also its foundation) seems to suggest that the relations between humans and machines per se might not be ontologically different from the relations of humans and nature - i.e., the immediate materiality of the human body does not exclude the use of the inorganic prosthesis, nor does it endanger the carnal experience - transformation and change are already primordially inherent characteristics of the enfleshed, carnal self, without which a self cannot even emerge, and the materiality at the core of any technology is per se not different from the lived materiality of the world.

The relationship with any "inorganic prosthesis", hence, could be understood through an understanding of a becoming, carnal self (leibliches Selbst) - grasped as an inbetweenness, a synthesis of "carnal being" (Leibsein) and the "body that we have" (Körper haben), incorporating, instead of dividing the dimensions of subjectivity and objectivity, where life is understood as a becoming - a tension between transformation fixation 
and transformation (beyond the dichotomy of life and death), which does not presuppose certain elements to be alien to life and lived carnality (inorganic). The use of biotechnologies and other technological developments does not automatically endanger human selfhood or promote a turn against nature, nor does it presuppose a transhuman self, "freed" from its mortal and material existence (Braidotti, 2013, 90-92).

The directionality towards certain elements in the modes of becoming or having as the discourse directionalities toward life (as striving toward creativity and generative powers) or death (as an amplified "death drive", i.e. a desire for stability, rationality, and fixation) are, thus, the basis for an ethical critique, rather than the ontological make-up itself and the dangers of invasive technologization must rather be associated with the dualist discourse of the Western society, stemming from an excessive alienation (amplified having directionality) of the anatomical body figure, and the ethical solutions for today's issues should rather be sought on the basis of a posthuman, neomaterial ontology of the becoming, carnal self.

\section{Acknowledgments}

This article is supported by the ERAF (European Regional Development Fund) Post-Doctoral Research Support Programme [project No. 1.1.1.2/VIAA/1/16/001, research application No. 1.1.1.2./VIAA/4/20/613, project "Onto-Genealogies: The Body and Environmental Ethics in Latvia].

\section{References}

Alaimo, Stacy. (2010) Bodily Natures: Science, Environment, and the Material Self. Bloomington: Indiana University Press.

Böhme, Gernot. (2003) Leibsein als Aufgabe: Leibphilosophie in pragmatischer Hinsicht. Kusterdingen: Die Graue Edition.

Böhme, Gernot. (2008a) Ethik leiblicher Existenz: Über unseren moralischen Umgang mit der eigenen Natur. Frankfurt/M.: Suhrkamp.

Böhme, Gernot. (2008b) Invasive Technisierung. Technikphilosophie und Technikkritik. Kusterdingen: Die Graue Edition.

Böhme, Gernot. (2019) Leib. Die Natur, die wir selbst sind. Frankfurt: Suhrkamp Verlag: Berlin.

Braidotti, Rosi. (2013) The Posthuman. Cambridge: Polity Press.

Buber, Martin. (1923) Ich un Du. Leipzig: Infelverlag.

Christ, Antje; Dörholt, Dorothe dir. (2018) A Lack of Women in Asia. Cologne: Bildersturm Filmproduktion. Available: https://archive.org/details/ALackOf WomenInAsiaDW Documentary. (Accessed February 27, 2019).

Darwin, Charles. (1871) The Descent of Man, and Selection in Relation to Sex. London: John Murray. 
Deleuze, Gilles. (1983) Nietzsche and Philosophy. Translated by Janis Tomlinson. London: The Athlone Press.

Deleuze, Gilles. (1991) Bergsonism, New York: Zone Books.

Deleuze, Gilles; Guattari, Felix. (2000) Anti-Oedipus. Capitalism and Schizophrenia. Translated by Robert Hurley et al. Minneapolis, MN: University of Minnesota Press.

Foucault, Michel. (1965) Madness and Civilization: A History of Insanity at the Age of Reason. Translated by Richard Howard. New York: Vintage Books.

Foucault, Michel. (1977) Discipline and Punish. The Birth of Prison. Translated by Alan Sheridan. New York: Pantheon.

Foucault, Michel. (1978) The History of Sexuality, Volume One. Translated by. Robert Hurley. New York: Vintage.

Fromm, Erich. (1964) The Heart of Man: Its Genius for Good and Evil. New York: Harper and Row.

Fromm, Erich. (1966) You Shall Be as Gods. A Radical Interpretation of the Old Testament and Its Tradition. New York: Holt, Rinehart and Winston.

Fromm, Erich. (1976) To Have or to Be? New York: Harper and Row.

Fromm, Erich. (1992a) The Art of Being. New York: The Continuum Publishing Company.

Fromm, Erich. (1992b) The Anatomy of Human Destructiveness. New York: Holt, Rinehart and Winston.

Fuchs, Thomas. (2013) Zwischen Leib und Körper. // Leib und Leben. Perspektiven für eine neue Kultur der Körperlichkeit. Hrsg. Marcus Knaup, Martin Hänhel. WBG: Darmstadt.

Grosz, Elizabeth. (2004) The Nick of Time. Politics, Evolution and the Untimely, Crow's Nest: Allen \& Unwin.

Hari, Johann. (2018) The Real Causes of Depression. // How to Academy. Available: https://youtu.be/Hfl3Yh7fS4g (Accessed February 21, 2020).

Illich, Ivan. (2016) Limits to Medicine. Medical Nemesis: The Expropriation of Health. New York: Marion Boyars.

Kierkegaard, Soren. (1980) Sickness Unto Death. Translated by Howard V. Hong. Edna H. Hong, Princeton: Princeton University Press.

Laqueur, Thomas Walter. (1992) Making Sex. Body and Gender from the Greeks to Freud. London: Harvard University Press.

Laqueur, Thomas Walter. (2004) Solitary Sex. A Cultural History of Masturbation, New York: Zone Books.

Levinas, Emmanuel. (1969) Totality and infinity. Pittsburgh, PA: Duquesne University Press.

Mayer, Emeran. (2016) The Mind-Gut Connection. Harper Wave.

Morgan, James. (2018) A group of people with an amphibious life have evolved traits to match. Available: https://www.economist.com/science-and-technology/2018/ 04/21/a-group-of-people-with-an-amphibious-life-have-evolved-traits-to-match (Accessed April 21, 2019).

Nietzsche, Friedrich W. (1999a) Sämtliche Werke: Kritische Studienausgabe, vol. 1, Die Geburt der Tragödie aus dem Geiste der Musik, ed. Giorgio Colli and Mazzino Montinari München: Deutscher Taschenbuch Verlag de Gruyter.

Nietzsche, Friedrich W. (1999b) Sämtliche Werke: Kritische Studienausgabe, vol. 4, Also sprach Zarathustra, ed. Giorgio Colli and Mazzino Montinari. München: Deutscher Taschenbuch Verlag de Gruyter.

Oksala, Johanna. (2004) What is Feminist Philosophy? Thinking Birth Phenomenologically. Available: https://www.radicalphilosophy.com/article/what-is-feministphenomenology (Accessed April 2, 2019). 
Oksala, Johanna. (2014) Freedom and Bodies. // Foucault. Key Concepts. London: Routledge.

Oksala, Johanna. (2016) Feminist Experiences. Foucauldian and Phenomenological Investigations. Studies in Phenomenology and Existential Philosophy, Northwestern University Press. Kindle Edition.

Radomska, Marietta. (2016). Uncontainable Life: A Biophilosophy of Bioart [PhD dissertation]. Linköping: Linköping University Electronic Press.

Rose, Nikolas; Abi-Rached, Joelle. (2013). Neuro: The New Brain Sciences and the Management of the Mind (Princeton University Press).

Sarasin, Philipp. (2000) Reizbare Maschinen, Eine Geschichte des Korpers 1765-1914. Frankfurt/M.: Suhrkamp.

Sarasin, Philipp. (2009) Darwin und Foucault. Genealogie und Geschichte im Zeitalter der Biologie. Frankfurt am Main: Suhrkamp.

Sarasin, Philipp. (2010) Michel Foucault. Zur Einführung. Hamburg: Junius.

Sauka, Anne. (2020a) Life in Process: The Lived-Body Ethics for Future // ReligiousPhilosophical Articles. XXVIII. Rīga: FSI, 2020, pp. 154-183.

Sauka, Anne. (2020b) The Nature of Our Becoming: Genealogical Perspectives // Le Foucaldien, 6(1). DOI: http://doi.org/10.16995/lefou.71

Sauka, Anne (2020c) A lack of meaning? Reactive nihilism and processual materiality // Approaching Religion, 10(2), pp. 125-40. DOI: https://doi.org/10.30664/ar.91788

Waldenfels, Bernhard. (2000) Das leibliche Selbst. Vorlesungen zur Phänomenologie des Leibes. Hrsg. von Regula Giuliani. Frankfurt/M.: Suhrkamp.

Waldenfels, Bernhard. (2004) Bodily experience between selfhood and otherness // Phenomenology and the Cognitive Sciences 3. Netherlands: Kluwer Academic Publishers, pp. 235-248.

Waldenfels, Bernhard. (2007) The Question of the Other. New York: The State University of New York Press. 